Sains Malaysiana 50(1)(2021): 181-189

http://dx.doi.org/10.17576/jsm-2021-5001-18

\title{
The Anticancer Compound Dolichol from Ceriops tagal and Rhizophora mucronata Leaves Regulates Gene Expressions in WiDr Colon Cancer
}

(Sebatian Anti-kanser Dolikol daripada Daun Ceriops tagal dan Rhizophora mucronata untuk Mengawal Pengekspresan Gen Sel Kanser Kolon WiDr)

\section{Meighina Atika Istiqomah, Poppy Anjelisa Zaitun Hasibuan, Arif Nuryawan, Sumaiyah Sumaiyah, ETTI SARTINA SIREGAR \& MOHAMMAD BASYUNI*}

\section{ABSTRACT}

Mangrove plants produce polyisoprenoid alcohol. The polyisoprenoid consists of polyprenol and dolichol, which in pharmacological activity act as anticancer agents. The major polyisoprenoid compound of mangrove plants Ceriops tagal and Rhizophora mucronata was reported as dolichol. The present study was conducted to examine the anticancer effects of dolichol from $\mathrm{C}$. tagal and R. mucronata leaves on WiDr cells and cell cycle-related cancer for $24 \mathrm{~h}$ and to evaluate the regulation of five genes, p53, EGFR, PI3K, Akt, and mTOR. The inhibited cell cycle was analysed by flow cytometry and the gene expression of p53, EGFR, PI3K, Akt, and mTOR was determined using reverse transcriptionpolymerase chain reaction (RT-PCR) method. Dolichol from $\mathrm{C}$. tagal was more effective than that from $\mathrm{R}$. mucronata, where it worked on the G0/G1 cycle for $87.94 \%$ and $82.36 \%$, respectively, and regulated positive control 5-FU on the G0/G1 cycle (88.12\%), $S$ (9.52\%) and G2-M (6.42\%). The upregulation (p53) and downregulation (EGFR) contributed to the contracting cell cycle of colon cancer cells (WiDr) in PI3K, Akt and mTOR genes. To summarise, the current study suggests significant pharmacological properties of dolichols in $\mathrm{C}$. tagal and R. mucronata leaves, which worked explicitly in the G0/G1 phase.

Keywords: Anticancer; Ceriops tagal; mangrove; polyisoprenoid; Rhizophora mucronata

ABSTRAK

Tumbuhan bakau menghasilkan alkohol poliisoprenoid. Poliisoprenoid terdiri daripada poliprenol dan dolikol yang bertindak sebagai agen anti-kanser dalam aktiviti farmakologi. Dolikol telah didapati sebagai sebatian poliisoprenoid utama dalam tanaman bakau Ceriops tagal dan Rhizophora mucronata. Kajian ini dijalankan untuk mengkaji kesan anti-kanser dolikol daripada daun C. tagal dan R. mucronata pada sel WiDr dan kanser yang berkaitan dengan kitaran sel selama 24 jam untuk menilai pengawalan lima gen, p53, EGFR, PI3K, Akt dan mTOR. Kitaran sel yang direncat telah dianalisis dengan sitometri aliran dan pengekspresan gen p53, EGFR, PI3K, Akt dan mTOR ditentukan menggunakan kaedah tindak balas polimerase berantai transkripsi berbalik (RT-PCR). Dolikol daripada C. tagal lebih berkesan daripada R. mucronata, kerana ia bertindak balas pada kitaran G0/G1, masing-masing dengan $87.94 \%$ dan $82.36 \%$ keberkesanan serta mengatur kawalan positif 5-FU pada kitaran G0/G1 (88.12\%), S (9.52\%) dan G2-M (6.42\%). Pengawalan-atas (p53) dan pengawalan-bawah (EGFR) menyumbang kepada pengurangan kitaran sel barah kolon (WiDr) pada gen PI3K, Akt dan mTOR. Sebagai kesimpulan, kajian semasa menunjukkan sifat farmakologi dolikol yang signifikan pada daun C. tagal dan R. mucronata, yang berfungsi secara berkesan dalam fasa G0/G1.

Kata kunci: Anti-kanser; bakau; Ceriops tagal; poliisoprenoid; Rhizophora mucronata

\section{INTRODUCTION}

Cancer is a disease where a collection of abnormal cells grows uncontrollably by diverting from the standard rules of cell division. Normal cells depend on signals that determine whether to divide and differentiate into other cells or die (Andersen \& Markham 2006). Cancer cells can develop the economic level of these signals, resulting in uncontrolled growth and proliferation. This proliferation results in fatality. Cancer cells themselves can make their blood vessels survive, which accelerates the growth and 
development of such cells throughout the body. Almost $90 \%$ of total deaths across the globe are cancer related, due to the spreading of tumours - a process called metastasis (Baeriswyl \& Christofori 2009). A type of cancer often experienced by women is breast cancer, whereas men suffer from colon cancer caused by unhealthy lifestyles and habits.

Mangrove plants are known to produce polyisoprenoid alcohol, which contains polyprenol and dolichol. Polyisoprenoids are long-chain secondary metabolites ( $>\mathrm{C} 50$ ) found in almost all living cells, occurring in various plant tissues (Swiezewska \& Danikiewicz 2005). Polyisoprenoids are known to have pharmacological properties, such as anticancer (Kuznecovs et al. 2007) and anti-dyslipidaemic (Singh et al. 2002). In this context, polyisoprenoid is a basic framework of several plant metabolites and these compounds are not toxic (Arung et al. 2009). The primary polyisoprenoid compound of mangrove plants, C. tagal and $R$. mucronata, was dolichol (Basyuni et al. 2017). Previous chemical investigations of $C$. tagal and $R$. mucronata leaves have shown them to contain flavonoids, glucosides, naphtha-quinone derivatives, hydrocarbons and triterpenes. These compounds have been reported to show antiviral, antimalarial, antibacterial, and antifungal activities (Hogg \& Gillan 1984).

Our foregoing studies demonstrated that polyisoprenoids from some mangrove plants such as Avicennia alba (Illian et al. 2019), A. marina and A. lanata (Illian et al. 2018), C. tagal and R. mucronata (Sari et al. 2018a), and Nypa fruticans (Sari et al. 2018b) decreased cell proliferation, arrested cell cycle, induced apoptosis and exhibited anticancer colon activity. However, the biological activities of dolichol have rarely been reported. Therefore, a study of the biological and pharmacological activities of dolichols is required to gain more insight into the treatment of toxic chemotherapy. The present work aims to examine the treatment of colon cancer using $C$. tagal and $R$. mucronata in terms of the cycle and gene expression of p53, EGFR, PI3K, Akt and mTOR, using the RT-PCR method in various inhibitions of growth and development of cancer cells.

\section{MATERIALS AND METHODS}

\section{PLANT MATERIALS AND ISOLATION OF POLYISOPRENOIDS}

C. tagal and R. mucronata leaves were collected from Lubuk Kertang mangrove forest, Langkat, North Sumatra Province, Indonesia, in February. The procedure for the extraction of polyisoprenoids was performed, as previously described (Illian et al. 2019). The C. tagal and $R$. mucronata leaves were first cleaned using tap water and then oven-dried at $60-75^{\circ} \mathrm{C}$ for 2 days. The powder of the leaves $(500 \mathrm{~g})$ of $C$. tagal and $R$. mucronata was macerated with chloroform:methanol $(2: 1, \mathrm{v} / \mathrm{v})$ for $48 \mathrm{~h}$, as previously reported (Illian et al. 2019). The lipid extract from the leaves was saponified at $65^{\circ} \mathrm{C}$ for one day in $86 \%$ ethanol containing $2 \mathrm{M} \mathrm{KOH}$. The non-saponifiable lipids (NSLs) of both mangrove leaves were extracted with hexane and the organic solvent was evaporated and re-dissolved in hexane (Basyuni et al. 2017). The NSL extracts $(50-100 \mathrm{mg})$ were analysed by thin layer chromatography (TLC) and RP-18 high-performance thin layer chromatography (HPTLC) plates (Merck, Darmstadt, Germany) to identify the polyisoprenoid composition. The polyisoprenoid compounds in C. tagal leaves were detected to be $100 \%$ dolichol family with chain length of C75-C85. Whereas, polyisoprenoid in $R$. mucronata leaves consisted of $9.8 \%$ polyprenol (C80-C90) and 90.2\% dolichol (C75-C95) (Basyuni et al. 2017). A two-dimensional TLC of both samples was carried out and triplicated, and the samples showed identical patterns; we confirmed that two mangrove leaves' extracts contained at least $90 \%$ dolichols and could be used for further investigation.

\section{CELL LINE AND CULTURE CONDITIONS}

A colon cancer cell culture (WiDr cells), human colon cancer cells, was derived from the large intestine of a 78-year-old woman. This cell was obtained from the collection of the Laboratory of Parasitology, Faculty of Medicine, Gadjah Mada University (Yogyakarta, Indonesia). Roswell Park Memorial Institute-1640 (RPMI 1640), 1\% penicillin and 1\% streptomycin were obtained from Gibco (Carlsbad, CA, USA), foetal bovine serum (FBS) and $0.5 \%$ fungizone were purchased from Sigma-Aldrich (St. Louis, MO, USA). The WiDr cell line was cultured in RPMI medium supplemented with $10 \%$ $(\mathrm{v} / \mathrm{v})$ FBS, $1 \%(\mathrm{v} / \mathrm{v})$ penicillin and streptomycin and $0.5 \%$ fungizone and was stored in a $37{ }^{\circ} \mathrm{C}$ incubator with $5 \%$ $\mathrm{CO}_{2}$, as previously reported (Illian et al. 2018; Sari et al. 2018b).

\section{PREPARATION OF STOCK SOLUTION}

Fifty $\mathrm{mg}$ polyisoprenoids from $R$. mucronata and from C. tagal were dissolved in $10 \mathrm{~mL}$ of RPMI 1640 medium using $1 \mathrm{~mL}$ DMSO (Sigma-Aldrich, St. Louis, MO, USA) to obtain a concentration of $5000 \mu \mathrm{g} / \mathrm{mL}$. The test solution was serially diluted with a concentration of $C$. tagal and R. mucronata dolichol for $1000 \mu \mathrm{g} / \mathrm{mL}, 500 \mu \mathrm{g} /$ $\mathrm{mL}, 250 \mu \mathrm{g} / \mathrm{mL}, 125 \mu \mathrm{g} / \mathrm{mL}$, and $62.5 \mu \mathrm{g} / \mathrm{mL}$ in the cell cycle analysis, as previously reported (Illian et al. 2018; Sari et al. 2018a). 
MEASUREMENT OF CELL CYCLE DISTRIBUTION USING FLOW CYTOMETRY

WiDr cells $\left(5 \times 10^{3}\right.$ cells/well $)$ were inserted in the well using six wells and then incubated for $24 \mathrm{~h}$. Subsequently, the cells were exposed to C. tagal and $R$. mucronata dolichol and then incubated for another 24 $\mathrm{h}$. The cells that floated and attached were collected by applying $0.025 \%$ trypsin and transferred into the cone tube. Thereafter, $1 \mathrm{~mL}$ of culture media was collected and added to the same conical tubes. One $\mathrm{mL}$ of phosphate buffered saline (PBS) was added to microplates and then the PBS washes were collected and added to the same conical tubes, followed by centrifugation at $600 \mathrm{rpm}$ for $5 \mathrm{~min}$ and the removal of the supernatants. Thereafter, the pellets were resuspended in $1 \mathrm{~mL}$ of PBS; then they were transferred to microtubes and centrifuged at 2500 rpm for 5 min.

The supernatant was removed and $1 \mu \mathrm{L}$ RNase/PI dye solution was added and maintained for $10 \mathrm{~min}$ in a dark place (avoiding light) at $37^{\circ} \mathrm{C}$; it was then analysed using the FACScan Flow cytometer. The percentage of cells obtained in each cell cycle phase (G1/S and G2/M) was calculated using Modfit Lt. 3.0 software (Verity Software House).

\section{MEASUREMENT OF GENES EXPRESSION USING RT-PCR}

The total RNA was extracted from the control and cultured cells $\left(7.5 \times 10^{8}\right.$ cells/well $)$ using the Total RNA Mini Kit (Geneaid), according to the manufacturer's protocol. The total RNA $(0.3 \mu \mathrm{g}$ each $)$ was reversetranscribed with $1 \mu \mathrm{g}$ random primer and ReverTra Ace (Toyobo) to produce a cDNA in a total volume of $20 \mu \mathrm{L}$ for $10 \mathrm{~min}$ at $30^{\circ} \mathrm{C}, 60 \mathrm{~min}$ at $42^{\circ} \mathrm{C}$ and $5 \mathrm{~min}$ at $99{ }^{\circ} \mathrm{C}$, as per the manufacturer's procedure. The resulting cDNA mixture was diluted in TE buffer solution and directly used for the subsequent PCRs. Semi-quantitative RTPCR for p53, EGFR, PI3K, Akt and mTOR genes (Dong et al. 2014; Hassan et al. 2012; Matsumoto et al. 2009; Nomani et al. 2012; Wang et al. 2014) was examined using $1 \mu \mathrm{L}$ cDNA added to $25 \mu \mathrm{L}$ PCR Master Mix (12.5 $\mu \mathrm{L}$ GoTaxGreen, $1 \mu \mathrm{L}$ primer forward and $1 \mu \mathrm{L}$ primer reverse (as listed in Table 1), and 9.5 $\mu \mathrm{L}$ DNase/RNasefree water). Semi-quantitative RT-PCR was carried out with $35-40$ cycles for $15-30 \mathrm{~s}$ at $94{ }^{\circ} \mathrm{C}, 45 \mathrm{~s} 94{ }^{\circ} \mathrm{C}$ and 10 $\mathrm{s}$ at $55-60{ }^{\circ} \mathrm{C}$, with the final extension phase at $72{ }^{\circ} \mathrm{C}$ for 5 min before being stored at $-20^{\circ} \mathrm{C}$ (Zhang et al. 2011). The semi-quantitative RT-PCR product was observed using $2 \%$ agarose gel and stained with ethidium bromide. The bands were documented using the image scanner Doc XR Gel (Bio-Rad). To quantify the PCR product, Quantity One 1-D analysis software (Bio-Rad) was used to measure the band intensity of the analysed genes. $\beta$-actin was an internal standard to normalise the PCR efficiency (Kamal et al. 2010).

\section{DATA ANALYSIS}

Data were statistically analysed using one-way ANOVA for density base pair of p53, EGFR, PI3K, Akt, and mTOR genes; then they were completed with a post-hoc test consisting of the Tukey HSD test. The value of $p<0.05$ was chosen as the threshold for statistical significance.

\section{RESULTS}

\section{INHIBITION ANALYSIS OF CELL CYCLES WITH FLOW} CYTOMETRY

The inhibition analysis of the cell cycle was carried out using the propidium iodide reagent with flow cytometry. The percentage of inhibition in each phase (cell control as a normal cell, 5-FU as a positive control, C. tagal dolichol and $R$. mucronata dolichol) is presented in Figure 1 and Table 2. The data demonstrate that normal cells as control cells possessed the lowest percentage of cell accumulation on G0/G1 but had the highest proportion in the G2-M phase (Figure 1A, Table 2). However, the accumulation of dolichol in C. tagal worked on the G0/ G1 phase, which was $87.94 \%$ (Figure 1C, Table 2). The cell accumulated on the G0/G1 phase that occurred in C. tagal was greater than dolichol from $R$. mucronata $(82.36 \%)$ (Figure 1D). Positive control of 5-FU, which worked on the $\mathrm{G} 0 / \mathrm{G} 1$ phase $(88.12 \%)$ too, had a slightly higher percentage than both $C$. tagal and $R$. mucronata (Figure 1D, Table 2). C. tagal and 5-FU had a percentage value of $\mathrm{G} 0 / \mathrm{G} 1$, which was almost the same as the difference in the value of $0.18 \%$ (Figure $1 \mathrm{~B}$ and $\mathrm{C}$, Table 2 ).

\section{EXPRESSION OF P53, EGFR, PI3K, AKT, AND MTOR GENES USING RT-PCR}

Figure 2 shows that semi-quantitative expression of $\mathrm{p} 53$, EGFR, PI3K, Akt, mTOR, and $\beta$-actin genes from C. tagal and $R$. mucronata were analysed based on a base pair of each gene by RT-PCR. The $\beta$-actin as the housekeeping gene showed the stability expression to the cell control, 5-FU, C. tagal and R. mucronata (Figure 2(A)-2(D)). The $\beta$-actin produced amplicon $100 \mathrm{bp}$. Figure 2(A) illustrates the bands of p53 expression with $390 \mathrm{bp}$ of PCR product (390), which shows a clear band in 5-FU. On the other hand, EGFR expressed (495 bp) in all samples tested in which cell control accumulated the largest band intensity (Figure 2). Both PI3K and Akt (195 and $330 \mathrm{bp}$ ), suppressor genes, occurred in all samples with the highest band intensity in R. mucronata dolichol. Furthermore, the mTOR gene showed 110 bands with strong intensity in the control cell and R. mucronata dolichol (Figure 2).

Figure 3 depicts the density value of the anti-apoptotic gene expression of p53 increases, compared to untreated control cells; by contrast, the expression of pro-apoptotic genes analysed, PI3K, Akt, mTOR and EGFR decreases against control cell. p53 was a tumour suppressor gene, 
the action prevented the growth of cancer cells and inhibited the development of colon cancer cells. RT-PCR showed that $C$. tagal dolichol was expressed lower than R. mucronata dolichol for the cases of EGFR, PI3K, Akt, and mTOR genes. In the case of p53, C. tagal dolichol was slightly higher gene expression than $R$. mucronata dolichol (Figure 3). The value of gene expression in $C$. tagal and $R$. mucronata had a significant difference against the control cell (Figure 3).
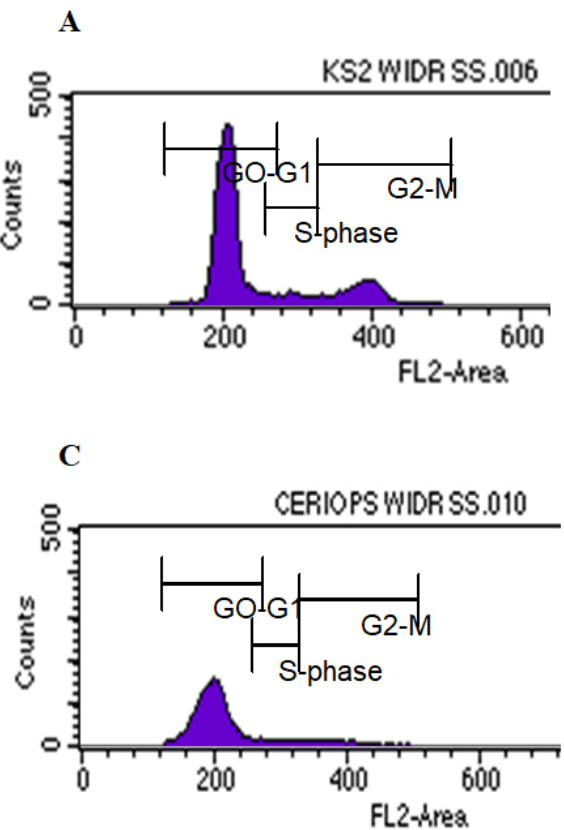

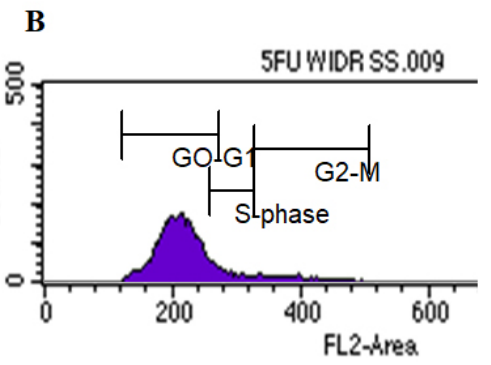

D

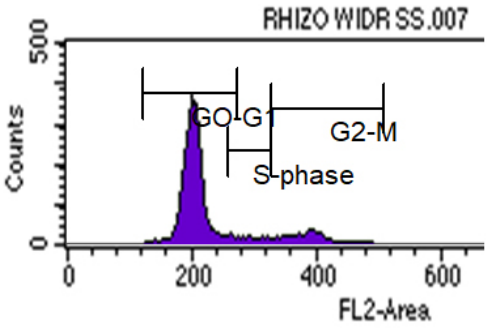

FIGURE 1. Cell cycle with flow cytometry methods with treatment control cell/ normal cells (A), 5-FU, positive control (B), C. tagal (C) and R. mucronata (D)

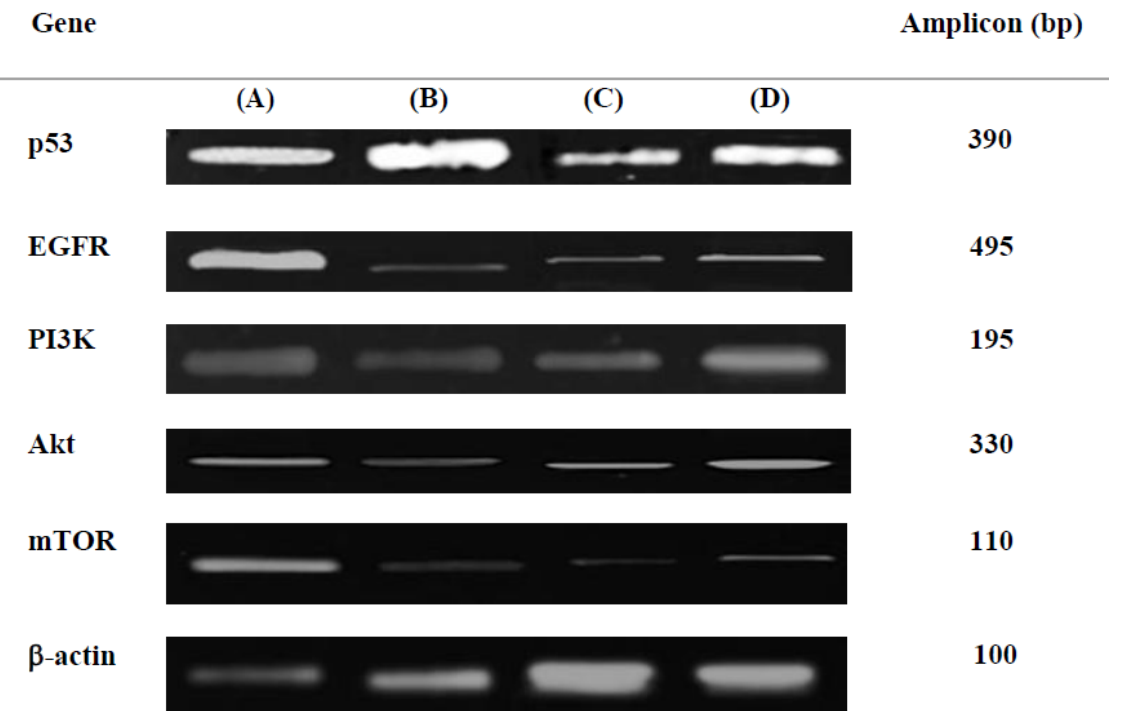

FIGURE 2. Gene expression of p53, EGFR, P13K, Akt, Mtor, and $\beta$-actin analysed by the RT- PCR method to the treatments of a control cell (A), 5-FU (B), C. tagal (C) and R. mucronata (D) 


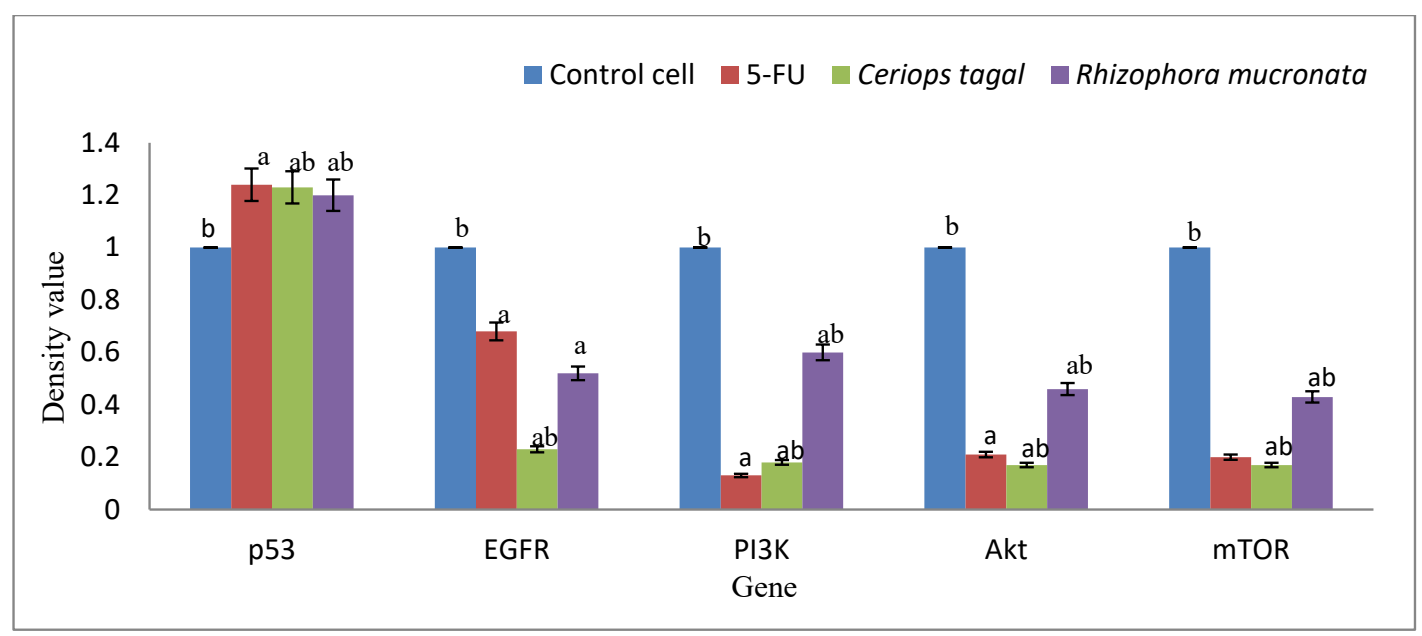

FIGURE 3. The density value of gene expression evaluated by a one-way post-hoc test, Tukey HSD; $\mathrm{a}=\operatorname{Sig}(P)<0.05$, a statistically significant difference with control cell; $\mathrm{b}=\operatorname{Sig}(P)<0.05$, a statistically significant difference with 5-FU; $\mathrm{c}=\operatorname{Sig}(P)>0.05$, not a significant difference with cell control; $\mathrm{d}=\operatorname{Sig}(P)>0.05$, not showing significant effect with 5-FU

Dolichols in C. tagal and $R$. mucronataleaves

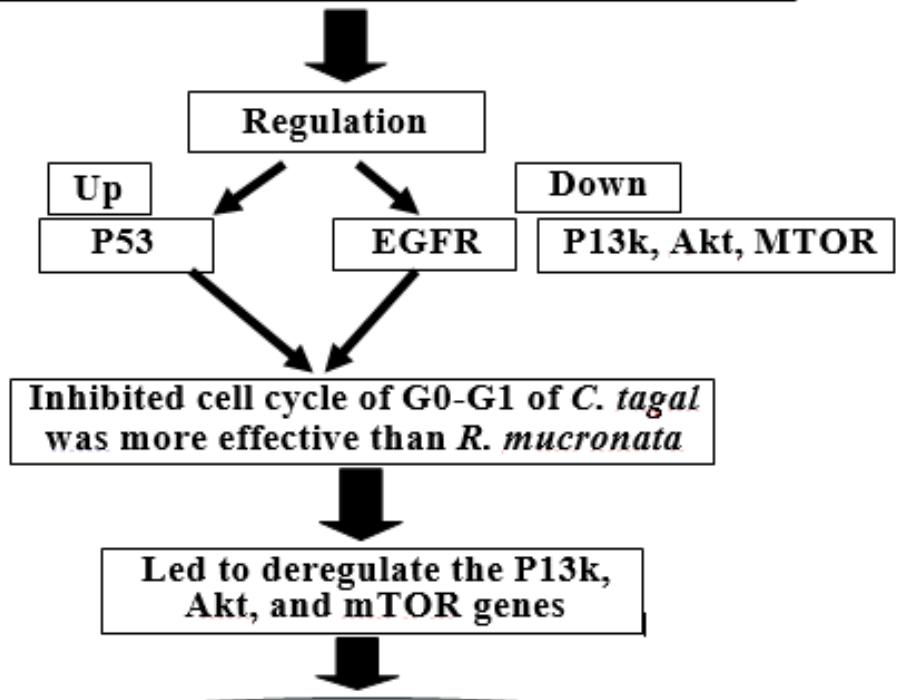

Dolichol of C. tagal and $R$. mucronata worked especiallyinWiDrcoloncancercellinG0-G1phase

FIGURE 4. The summary of dolichol from C. tagal and R. mucronata leaves as the anticancer in WiDr colon cancer cell lines 
TABLE 1. Description for the RT-PCR primers

\begin{tabular}{|c|c|c|c|}
\hline Gene & & Sequence $\left(5^{\prime}-3{ }^{\prime}\right)$ & Length (bp) \\
\hline \multirow[t]{2}{*}{ p53 } & $\mathrm{F}:$ & ATTCAGCTCCTCCTCCATGAAGAATCGGCG & 390 \\
\hline & $\mathrm{R}$ : & GCTTTGCTGCTGAGGCCACCAGTATCCACT & \\
\hline \multirow[t]{2}{*}{ EGFR } & $\mathrm{F}:$ & CGACAACATAAGCTCCCA & 495 \\
\hline & $\mathrm{R}:$ & CGCCGAAACTTTCTAGGGT & \\
\hline \multirow[t]{2}{*}{ PI3K } & $\mathrm{F}:$ & CCAGGAATTTCGCAGCAA & 195 \\
\hline & $\mathrm{R}:$ & TGCTGGTGGTTTCTGGAT & \\
\hline \multirow[t]{2}{*}{ Akt } & $\mathrm{F}:$ & ATGATTGCTAGCGTGGTGGACAAT & 330 \\
\hline & $\mathrm{R}:$ & GAGGCCAGCCACGTCAGTCTGGATG & \\
\hline \multirow[t]{2}{*}{ mTOR } & $\mathrm{F}:$ & CCAATTCAGATCCGCATTTCC & 110 \\
\hline & $\mathrm{R}$ : & AACAAACTCGTTGCTTCCATGG & \\
\hline \multirow[t]{2}{*}{$\beta$-actin } & $\mathrm{F}:$ & GCTCCTCCTAAGCGCGAGT & 100 \\
\hline & $\mathrm{R}$ : & TCATACTCGCTGTCCTGCATTTG & \\
\hline
\end{tabular}

p53, tumour protein; 53, epidermal growth factor receptor (EGFR); PI3k, Phosphoinositide 3-kinase; Akt, protein kinase B; V-akt, murine thymoma viral oncogene homolog; mTOR, Mechanistic Target of Rapamycin Kinase; $\beta$-actin, beta-actin

TABLE 2. Accumulated values in each phase of the cell cycle of WiDr cells treated with of mangrove leaves C. tagal and R. mucronata

\begin{tabular}{lcccc}
\hline Sample & Concentration $(\mu \mathrm{g} / \mathrm{mL})$ & \multicolumn{2}{c}{ Phase of the cell cycle $(\%)$} \\
& & $\mathrm{G} 0-\mathrm{G} 1$ & $\mathrm{~S}$ & $\mathrm{G} 2-\mathrm{M}$ \\
\hline Control cell & - & 76.63 & 7.22 & 17.93 \\
C. tagal & $1 / 5 \mathrm{IC}_{50}$ & 87.94 & 6.39 & 7.54 \\
R. mucronata & $1 / 5 \mathrm{IC}_{50}$ & 82.36 & 6.63 & 12.86 \\
5-FU & $1 / 5 \mathrm{IC}_{50}$ & 88.12 & 9.52 & 6.42 \\
\hline
\end{tabular}

\section{DISCUSSION}

The current data allowed us to investigate the possible mechanism of dolichol in C. tagal and R. mucronata as anticancer agents against WiDr colon cancer cells by investigating cellular inhibition property of dolichol and the expression of suppressor and inhibitor genes. In this study, a higher percentage of both $C$. tagal and R. mucronata dolichol in the G0/G1 phase that controls cells showed accelerated cells in the preparation of DNA material, which was synthesised. This study result agrees with previous works that state that polyisoprenoids from $R$. mucronata and C. tagal leaves significantly induce apoptosis and cause cell cycle arrest in the G0/G1 phase
(Sari et al. 2018a). It has been shown that the cellular accumulation of WiDr with $C$. tagal and R. mucronata dolichol in the G0/G1 phase was higher, as compared to the cell control. This finding suggests that the mechanism of inhibition of $C$. tagal and $R$. mucronata dolichol on the cell cycle in WiDr cells was in the G0/G1 phase. In this circumstance, the growth and development of cancer cells were inhibited. C. tagal and R. mucronata dolichol have worked in G0/G1 phase but not specifically in $\mathrm{S}$ and G2/M phases. Moreover, when compared with the positive control (5-FU), C. tagal dolichol produced similar levels of orange fluorosis, indicating that $C$. tagal dolichol may have a position similar to this first-line treatment for colon cancer (5-FU). 
The first line of colon cancer treatment is 5-FU, an antimetabolite that works antagonically with thymine against the activity of the enzyme thymidylate synthase (TS). 5-FU is a prodrug, and the metabolism of 5-FU produces fluoridin-5-triphosphate (FUTP), which combines into RNA and affects its function, and fluorodeoxyuridylate (FdUMP), which inhibits DNA replication. 5-FU specifically works by blocking DNA replication (the preparatory phase) and this has the same effect and results as the mechanism of $C$. tagal that works dominantly in the G0/G1 phase (87.94\%). Therefore, this finding meets our target, namely $C$. tagal, which is able to work as a chemotherapy agent in colon cancer cells (WiDr) by proving cell cycle testing and expression of genes that play an active role in the occurrence of cancer. Several studies have reported that mangrove polysioprenoids, including dolichol, inhibited cyclooxygenase 2 (COX-2) expression (Illian et al. 2019, 2018; Sari et al. 2018a, 2018b) COX-2 produces prostaglandin E2 (PGE2), which is the most dominant type of hormones found in malignant cells. PGE2 binds to receptors on the cell surface, which are types of $G$ protein-coupled (GPCR) receptors, namely EP-1, EP-2, EP-3, and EP-4. The PGE2 bond with the EP receptor increases the levels of Bcl-2, a downregulated antiapoptotic gene, in the process of apoptosis, which increases cancer cell proliferation. In addition to increasing the B-cell lymphoma 2 (Bcl-2) gene, PGE2 and EP bonds also induce vascular endothelial growth factor (VEGF) expression, an important factor in angiogenesis that makes cancer cells get nutrients and oxygen and can be used to connect with blood (Wang \& Dubois 2004). The relationship of COX-2, which causes increased cancercell proliferation, is mediated by the bond between PGE2 and EGFR; the bond activates phosphoinositide 3-kinase (PI3K).

Furthermore, PI3K produces PIP-3 that activates PDK-1. This protein phosphorylates to activate Akt/ $\mathrm{PKB}$, responsible for the progression and transfer of cancer cells (Sobolewski et al. 2010). COX-2 is essential in the formation of prostaglandin as a trigger for VEGF expression. Furthermore, depression of VEGF inhibits angiogenesis, namely the process of forming new blood vessels collected in the process of cell transfer (metastasis) and the handling of premature cancer cells that can survive (Fosslien 2001).

The examination of the cell cycle, using the flow cytometry on WiDr cells, was carried out by the colouring method, as previously described (Illian et al. 2018). Propidium iodide was used to describe DNA to be detected by the fluorescence-activated cell sorting (FACS) detector. The phases in the normal cycle differ in the number of chromosome sets, namely G1; the number of sets of chromosomes is $2 \mathrm{~N}$. The $\mathrm{S}$ phase is $2 \mathrm{~N}$ and
$4 \mathrm{~N}$, while the $\mathrm{G} 2$ phase is Backward $4 \mathrm{~N}$. The number of different sets of chromosomes will be the basis for determining the intensity of fluorescence obtained in the flowcytometry tool - the more regulating the chromosomes, the greater the intensity of fluorescence (Doležel 1991). The event of apoptosis occurs through the activation of a protease called caspase as a pro-apoptotic protein and the Bcl-2 family, known as anti-apoptotic. Cell death occurs when caspase- 3 has been activated, causing the cell nucleus to break due to the ability of caspase- 3 to break down protein substrates, including DNA repairs such as poly (ADP-ribose) polymerase (PARP) and DNA protein kinases such as structural proteins, nucleoids, and endonucleases. In addition, caspase- 3 can activate other caspases such as procaspases 6 and 7, which have an impact on cell damage amplification (Elmore 2007).

In this study, $C$. tagal and $R$. mucronata dolichol upregulated the p53 gene expression. Mutations in the p53 gene are the most common genetic changes in human cancer; in vivo and in vitro studies show that the apoptotic pathway depends on the p53 gene (Ajay et al. 2010). The p53 gene can induce apoptosis and work with growth factors to determine whether induction of the apoptotic pathway occurs (Vogelstein \& Kinzler 1992). Tumour suppressing genes (p53) and apoptotic regulation play an important role in the pathogenesis of tumours. The p53 gene plays a role in cellular DNA damage by inhibiting cell progression and in spurring the apoptotic pathway if cell DNA-damage pathways cannot be repaired. The loss of p53 gene function and regulation of apoptosis causes loss of control in the cell cycle, resulting in the proliferation of cells that have DNA damage and that are highly likely to become cancerous (Ajay et al. 2010; Vogelstein \& Kinzler 1992). The present study is summarised in Figure 4, showing that dolichol from C. tagal and R. mucronata leaves upregulated p53 expression and downregulated EGFR, P13K, Akt, and mTOR of colon cancer cells (WiDr) that work in the cycle G0/G1 in the life cycle of cancer cells. The inhibition of cell cycle in the $\mathrm{G} 0 / \mathrm{G} 1$ phase that contributed to deregulating P13K, Akt, and mTOR genes suggested the involvement of dolichols in the colon cancer cell. To strongly support these findings, in vivo experiments on dolichol compounds as anticancer agents are needed for further investigations.

\section{CONCLUSION}

This study confirms that dolichol of C. tagal leaves provides significant pharmacological properties, was more effective than $R$. mucronata leaves and works correctly in the G0/G1 phase, which opens up other possibilities for the mangrove's use. Dolichol from both $C$. tagal and R. mucronata leaves upregulated 
p53 expression and downregulated EGFR, PI3K, Akt, and mTOR expression. This study shows that dolichol in C. tagal and R. mucronata blocked the growth and development of colon cancer cells (WiDr). C. tagal can be an alternative drug to 5-FU for colon cancer treatment by continuing in vivo tests to standard clinical and preclinical trials in the next experiments.

\section{ACKNOWLEDGEMENTS}

This study was supported by the Directorate General of Research and Community Service, the Ministry of Research, and Technology/National Agency for Research and Innovation of the Republic of Indonesia through World-Class Research Program 2020 (No. 214/SP2H/ AMD/LT/DRPM/2020) and Program Tesis Magister (PTM) 2019 (No. 11/E1/KP.PTNBH/2019).

\section{REFERENCES}

Ajay, A.K., Upadhyay, A.K., Singh, S., Vijayakumar, M.V., Kumari, R., Pandey, V., Boppana, R. \& Bhat, M.K. 2010. Cdk5 phosphorylates non-genotoxically overexpressed p53 following inhibition of PP2A to induce cell cycle arrest/ apoptosis and inhibits tumor progression. Molecular Cancer 9: 204-218.

Andersen, Q.M. \& Markham, K.R. 2006. Flavonoid: Chemistry, biochemistry, and applications. Angewandte Chemie 45(41): 6787-6787.

Arung, E.T., Wicaksono, B.D., Handoko, Y.A., Kusuma, I.Y., Yulia, D. \& Sandra, F. 2009. Anticancer properties of diethyl ether extract of wood from sukun (Artocarpus altilis) in human breast cancer (T47D) cells. Tropical Journal of Pharmaceutical Research 8(4): 317-324.

Baeriswyl, V. \& Christofori, G. 2009. The angiogenic switch in carcinogenesis. Seminars in Cancer Biology 19(5): 329-337.

Basyuni, M., Sagami, H., Baba, S. \& Oku, H. 2017. Distribution, occurrence, and cluster analysis of new polyprenyl acetones and other polyisoprenoids in North Sumatran mangroves. Dendrobiology 78: 18-31

Doležel, J. 1991. Flow cytometric analysis of nuclear DNA content in higher plants. Phytochemical Analysis 2(4): 143154.

Dong, M., Yang, G., Liu, H., Liu, X., Lin, S. \& Sun, D. 2014. Aged black garlic extract inhibits HT29 colon cancer cell growth via the PI3K/Akt signaling pathway. Biomedical Reports 2(2): 250-254.

Elmore, S. 2007. Apoptosis: A review of programmed cell death. Toxicologic Pathology 35(4): 495-516.

Fosslien, E. 2001. Molecular pathology of cyclooxygenase-2 in cancer induced angiogenesis. Annals of Clinical \& Laboratory Science 31(4): 325-348.

Hassan, Z.K., Elamin, M.H., Daghestani, M.H., Omer, S.A., Al-Olayan, E.M., Elobeid, M.A., Virk, P. \& Mohammed, O.B. 2012. Oleuropein induces anti-metastatic effects in breast cancer. Asian Pacific Journal of Cancer Prevention 13(9): 4555-4559.
Hogg, R.W. \& Gillan, FT. 1984. Fatty acids, sterols and hydrocarbons in the leaves from eleven species of mangrove. Phytochemistry 23(1): 93-97.

Illian, D.N., Hasibuan, P.A.Z., Sumardi, S., Nuryawan, A., Wati, R. \& Basyuni, M. 2019. Anticancer activity of polyisoprenoids from Avicennia alba blume in WiDr cells. Iranian Journal of Pharmaceutical Research 18(3): 14771487.

Illian, D.N., Basyuni, M., Wati, R. \& Hasibuan, P.A.Z. 2018. Polyisoprenoids from Avicennia marina and Avicennia lanata inhibit WiDr cells proliferation. Pharmacognosy Magazine 14(58): 513-518.

Kamal, A., Reddy, K.S., Khan, M.N. \& Shetti, R.V. 2010. Synthesis, DNA-binding ability and anticancer activity of benzothiazole/benzoxazole-pyrrolo $[2,1-c][1,4]$ benzodiazepine conjugates. Bioorganic and Medicinal Chemistry 18(13): 4747-4761.

Kuznecovs, S., Jegina, K. \& Kuznecovs, I. 2007. Inhibition of P-glycoprotein by polyprenol in human breast cancer cells. The Breast Journal 16(1): 515-521.

Matsumoto, K., Arao, T., Tanaka, K., Kaneda, H., Kudo, K., Fujita, Y., Tamura, D., Aomatsu, K., Tamura, T., Yamada, Y., Saijo, N. \& Nishio, K. 2009. mTOR signal and hypoxiainducible factor-1 $\alpha$ regulate CD133 expression in cancer cells. Cancer Research 69(18): 7160-7164.

Nomani, A., Fouladdel, S., Haririan, I., Rahimnia, R., Ruponen, M. \& Gazori, T. 2012. Poly (amidoamine) dendrimer silences the expression of epidermal growth factor receptor and 553 gene in vitro. African Journal of Pharmacy and Pharmacology 6(8): 530-537.

Sari, D.P., Basyuni, M., Hasibuan, P.A.Z., Wati, R. \& Sumardi. 2018a. Cytotoxic effect of polyisoprenoids from Rhizophora mucronata and Ceriops tagal leaves against WiDr colon cancer cell lines. Sains Malaysiana 47(9): 1953-1959.

Sari, D.P., Basyuni, M., Hasibuan, P.A., Sumardi, S., Nuryawan, A. \& Wati, R. 2018b. Cytotoxic and antiproliferative activity of polyisoprenoids in seventeen mangroves species against WiDr colon cancer cells. Asian Pacific Journal of Cancer Prevention 19(12): 3393-3400.

Singh, B., Sahu, P.M. \& Sharma, M.K. 2002. Antiinflammatory and anti-microbial activities of triterpenoids from Strobilanthes callosus nees. Phytomedicine 9(4): 355-359.

Sobolewski, C., Cerella, C., Dicato, M., Ghibelli, L. \& Diederich, M.M. 2010. The role of cyclooxygenase-2 in cell proliferation and cell death in human malignancies. International Journal of Cell Biology 2010: 1-21.

Swiezewska, E. \& Danikiewicz, W. 2005. Polyisoprenoids: Structure, biosynthesis, and function. Progress in Lipid Research 44(4): 235-258.

Vogelstein, B. \& Kinzler, K.W. 1992. P53 function and dysfunction. Cell 70(4): 523-526.

Wang, D. \& Dubois, N.R. 2004. Cyclooxygenase-2 derived prostaglandin E2 regulates the angiogenic switch. Proceedings of the National Academy of Sciences of the United States of America 101(2): 415-416. 
Wang, H., Duan, L., Zou, Z., Li, H., Yuan, S., Chen, X., Zhang, Y., Li, X., Sun, H., Zha, H., Zhang, Y. \& Zhou, L. 2014. Activation of the PI3K/Akt $/ \mathrm{mTOR} / \mathrm{p} 70 \mathrm{~S} 6 \mathrm{~K}$ pathway is involved in S100A4-induced viability and migration in colorectal cancer cells. International Journal of Medical Sciences 11(8): 841-849.

Zhang, Y., Dong, B., Guan, X.Y. \& Zhao, M. 2011. Expression of MMP-9 and WAVE3 in colorectal cancer and its relationship to clinicopathological features. Journal of Cancer Research and Clinical Oncology 138(12): 20352044.

Meighina Atika Istiqomah, Poppy Anjelisa Zaitun Hasibuan \& Sumaiyah Sumaiyah

Department of Pharmacology

Faculty of Pharmacy

Universitas Sumatera Utara

Medan, North Sumatra

Indonesia

Mohammad Basyuni* \& Arif Nuryawan

Department of Forestry

Faculty of Forestry

Universitas Sumatera Utara

Medan, North Sumatera

Indonesia
Mohammad Basyuni* \& Arif Nuryawan

Center of Excellence for Mangrove

Universitas Sumatera Utara

Medan, North Sumatra

Indonesia

Etti Sartina Siregar

Department of Biology

Faculty of Mathematics and Natural Sciences

Universitas Sumatera Utara

Medan, North Sumatra

Indonesia

*Corresponding author; email: m.basyuni@usu.ac.id

Received: 16 February 2020

Accepted: 22 June 2020 